\title{
Single-visit Feeding Obturator Fabrication in Infants with Cleft Lip and Palate: A Case Series and Narrative Review of
} Literature

\author{
Sunny P Tirupathi ${ }^{1}$, Rajesh Ragulakollu ${ }^{2}$, Vamsikrishna Reddy ${ }^{3}$
}

\begin{abstract}
Cleft lip and palate (CLP) is one of the most common craniofacial anomaly affecting newborns. In the early years of life to survive baby requires nutrition from the mother. Lip seal of infant is affected because of cleft palate and thereby feeding is greatly compromised. As there is communication between nasal cavity and oral cavity there are more chances of aspiration of milk into the lungs. The main role of pedodontist is to fabricate a palatal obturator which facilitates feeding. In this article we have discussed fabrication of feeding obturator in single visit in infants with cleft palate.

Keyword: Cleft lip and palate, Feeding plate, Infant, Obturator, Single visit

International Journal of Clinical Pediatric Dentistry (2020): 10.5005/jp-journals-10005-1723
\end{abstract}

\section{INTRODUCTION}

Cleft lip and palate (CLP) is the most common craniofacial anomaly affecting one in every 600 live births. Global prevalence rates of cleft palate may vary. According to systematic review conducted by Panamonta et al. on the prevalence of CLP varies $1.57-0.57$ per 1,000 live births. The American Indians had the highest prevalence rates of 2.62 per 1,000 live births, followed by the Japanese, the Chinese, and the Whites of $1.73,1.56$, and 1.55 per 1,000 live births, respectively. The Blacks had the lowest rate of 0.58 per 1,000 live births. ${ }^{1}$ Cleft lip and palate can have either syndromic or nonsyndromic etiology, and majority are nonsyndromic. ${ }^{2}$ Family history of clefts, advanced maternal age, pregestational hypertension, gestational seizures are significant risk factors. Paternal tobacco smoking is associated with increased risk. ${ }^{3}$ Syndromes associated with cleft lip palate-Van der Woude syndrome, velocardiofacial syndrome, median facial dysplasia, Pierre Robin sequence, Treacher Collins malformation, trisomies 13 and 18, Apert's syndrome, Stickler's syndrome, and Waardenburg's syndrome. ${ }^{2}$

\section{Associated Malformations}

Associated malformations are reported to be more frequent in infants who had both CLP than in infants with isolated cleft palate or infants with isolated cleft lip. ${ }^{2}$ Malformations of the limbs or vertebral column, cardiovascular system, congenital heart disease, mental retardation, and chromosomal anomalies are the most commonly associated malformations. ${ }^{2}$

Feeding is the first and foremost requisite for infants. Feeding is relatively difficult in infants with CLP. Until the lip and palate are surgically closed, feeding is a large difficulty for some infants and parents. ${ }^{4}$ Surgical closure of the palate can be accomplished later, usually between 9 months and 18 months of age to promote proper speech development. ${ }^{4}$ Feeding difficulties can cause problems with weight gain, resulting in a slower growth for the infant with a cleft. ${ }^{5-7}$ Other factors that can cause delayed weight gain and growth in infants with cleft palate or in infants with cleft lip and/or palate include chronic infections, metabolic disorders, 1,30partment of Pedodontics and Preventive Dentistry, Malla Reddy Institute of Dental Sciences, Hyderabad, Telangana, India

${ }^{2}$ Department of Pedodontics and Preventive Dentistry, KLRs Lenora Institute of Dental Sciences, Rajahmundry, Andhra Pradesh, India

Corresponding Author: Sunny PTirupathi, Department of Pedodontics and Preventive Dentistry, Malla Reddy Institute of Dental Sciences, Hyderabad, Telangana, India, Phone: +91 9490549454, e-mail: dr. priyatham@gmail.com

How to cite this article: Tirupathi SP, Ragulakollu R, Reddy V. Singlevisit Feeding Obturator Fabrication in Infants with Cleft Lip and Palate: A Case Series and Narrative Review of Literature. Int J Clin Pediatr Dent 2020;13(2):186-191.

Source of support: Nil

Conflict of interest: None

manifestations with syndromes, and multiple hospitalizations. ${ }^{5-7}$ It is of great importance to ensure that the infant with CLP is able to feed to maintain weight and normal growth. ${ }^{4}$

Feeding obturators will improve the ability of infant to attain suction and help the infant to feed adequately. It is necessary for the infant to have a sustained weight gain prior to surgery to correct the cleft lip and/or palate. ${ }^{8}$ This article aimed to report impression techniques for single-visit feeding obturator fabrication in different types of clefts in infants.

\section{Steps in Feeding Obturator Fabrication}

Two-step impression technique is recommended. Impression is taken when infant is in fully awake and no premedication was given. Infant was placed on helpers lap in supine position (Fig. 1).

\section{Preliminary Impression}

Modeling wax is softened in warm water and adapted to the contours of palate with the help of fingers, which is then carefully taken out from infants oral cavity without deformation or distortion (Fig. 2). Palatal (intaglio) surface of adapted modeling wax is dipped

() The Author(s). 2020 Open Access This article is distributed under the terms of the Creative Commons Attribution 4.0 International License (https://creativecommons. org/licenses/by-nc/4.0/), which permits unrestricted use, distribution, and non-commercial reproduction in any medium, provided you give appropriate credit to the original author(s) and the source, provide a link to the Creative Commons license, and indicate if changes were made. The Creative Commons Public Domain Dedication waiver (http://creativecommons.org/publicdomain/zero/1.0/) applies to the data made available in this article, unless otherwise stated. 


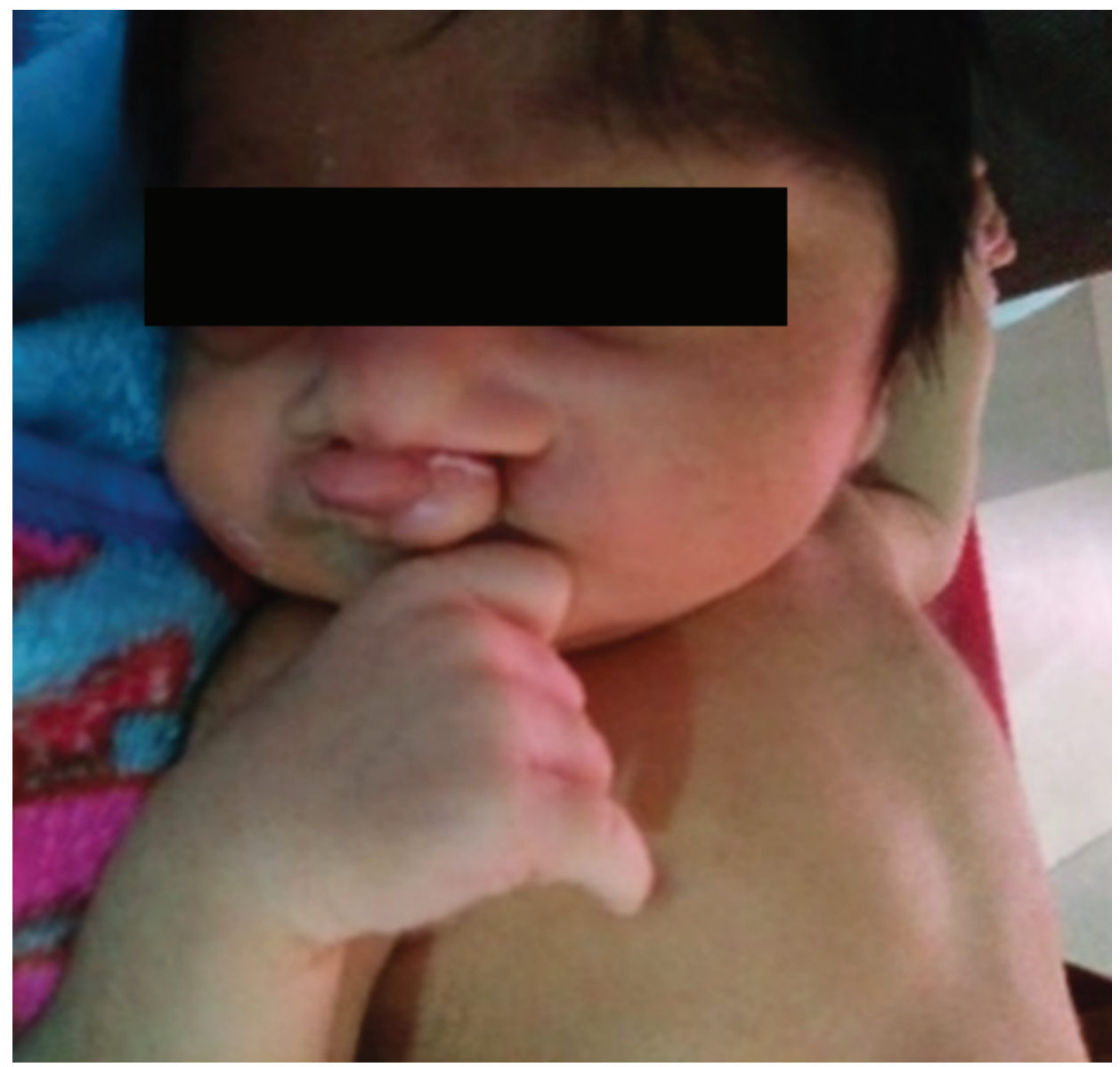

Fig. 1: Infant with complete bilateral cleft

in a semiliquid stage of plaster mix to create a primary cast on which custom tray is prepared with ethylene vinyl acetate sheet (Fig. 3). This custom tray is attached to ice-cream stick with the help of double-sided adhesive tape (Fig. 4)

\section{Secondary Impression}

Secondary impression is taken with the fast-setting addition silicone putty (Zhermack elite HD+ putty soft). Secondary impression material is loaded onto the custom tray and custom tray is supported by ice cream sick while making impression (Fig. 5). Custom tray is supported with the help of holding handle of ice cream stick with thumb and index finger and middle finger is placed at the posterior most extension of the custom tray. Proper adaptation can be achieved by encouraging the child to cry this can be accomplished by gently tapping the child on the foot. Very gentle pressure is applied on custom tray in upward and forward directions. During the impression making, two operators were available all the times with high-volume suction and a tweezer to ensure that any obstruction in the airway is cleared. And one operator should be available all the time to observe the infant while taking impression. Absence of crying and face becoming pale are the indications of airway obstruction and to be dealt accordingly. Master cast is prepared with type $V$ dental stone (Fig. 6) on which obturator is prepared using thermoplastic ethylene vinyl acetate sheet (2 layered) using biostar vacuum-forming machine. Final obturator was cut, trimmed, and polished and checked for fit, and before delivery, a hole was placed and 10-inch floss was tied to stabilize during feeding. Appliance was tried in infant's oral cavity, and parents were instructed about the placement and removal of palatal feeding obturator and instructions were given about cleaning and storage of appliance.

\section{Case Descriptions}

\section{Case 1}

A 7-day-old infant with CLP was referred to the Department of Pedodontics and Preventive Dentistry, Malla Reddy Institute of Dental Sciences, Hyderabad, Telangana, India (Fig. 1). General examination revealed no abnormality. Extra-oral and intraoral examinations revealed complete bilateral clefts (class-IV veaus classification). Feeding difficulty and nasal regurgitation were reported by the mother. Feeding obturator was fabricated as mentioned above.

\section{Case 2}

A 10-day-old child with unilateral cleft and palate reported to the Department of Pedodontics and Preventive Dentistry, Malla Reddy Institute of Dental Sciences. No other medical abnormality was detected except unilateral complete cleft palate (class-III veaus classification) (Fig. 7).

\section{Case 3}

A 2-month-old male child with uvula-pharyngeal cleft was previously reported to the Department of Pedodontics and Preventive Dentistry, Malla Reddy Institute of Dental Sciences, 45 days ago. The feeding obturator was fabricated in the similar manner as described above. The parents of the child reported 


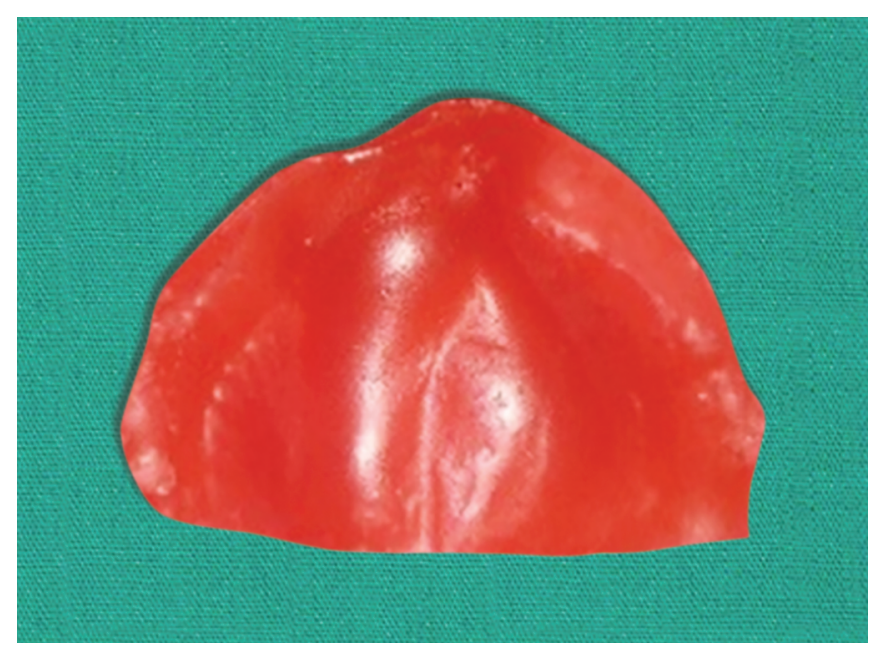

Fig. 2: Wax sheet preliminary impression

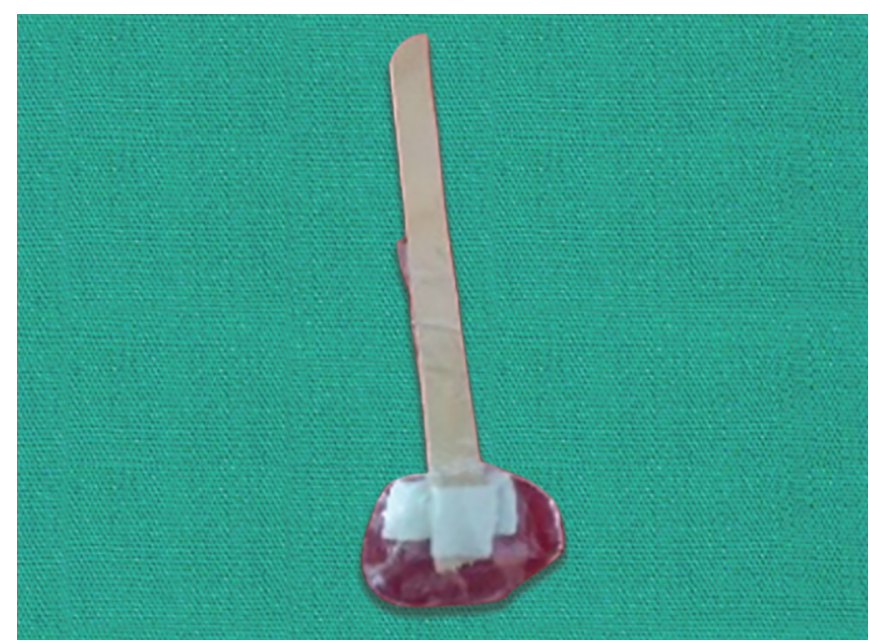

Fig. 4: Custom tray attached to ice-cream stick

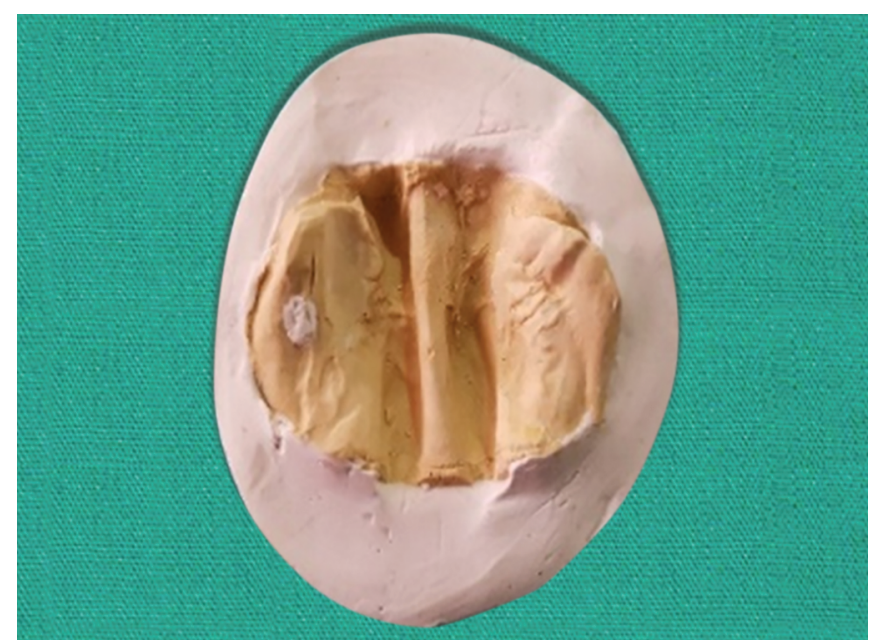

Fig. 6: Master cast

the feeding plate did not fit properly. This is due to an increase in the growth of jaws. In such cases, refabrication of feeding plate is necessary. Old feeding plate was used as a special tray and it is attached to an ice-cream stick using double-sided adhesive tape. This old feeding plate is loaded with secondary impression

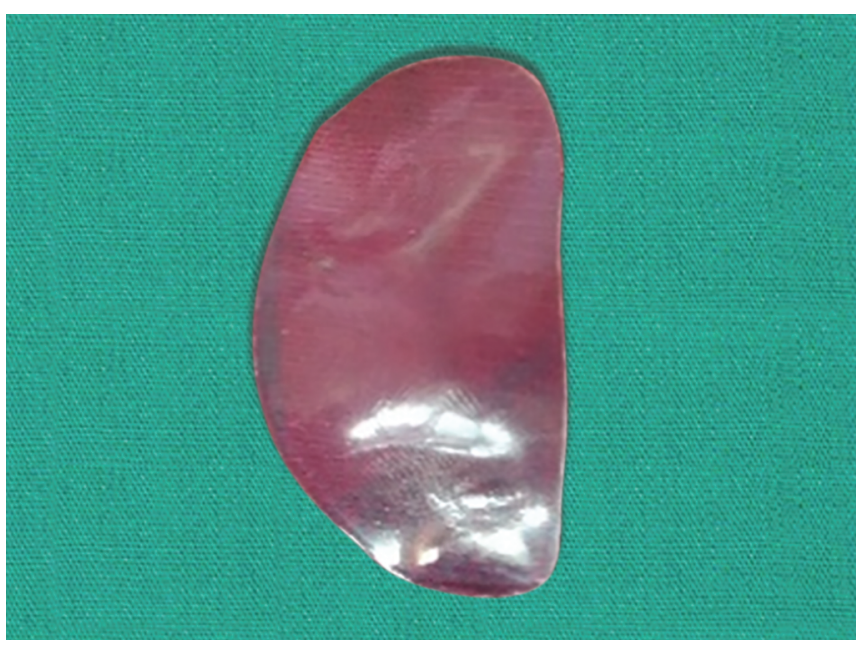

Fig. 3: EVA sheet custom tray

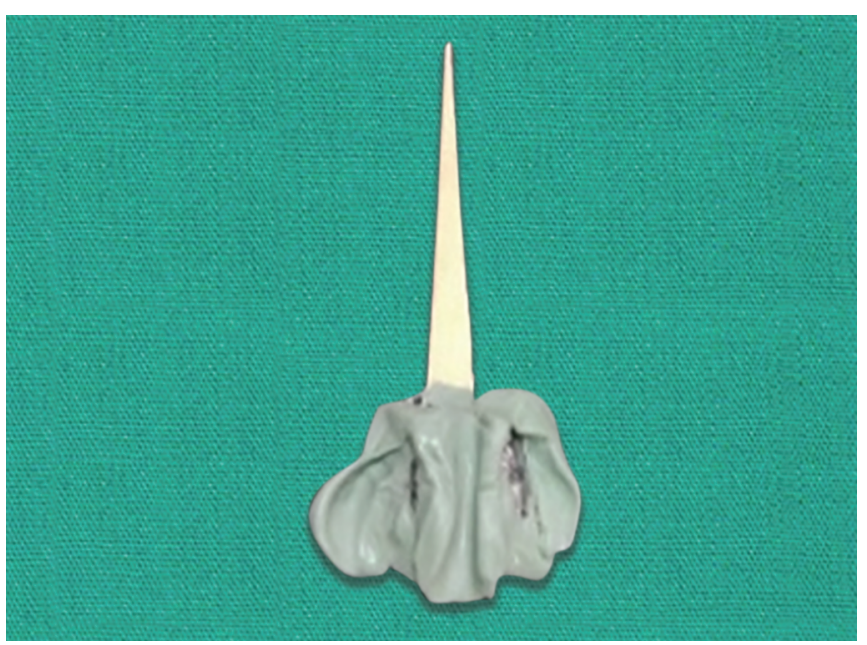

Fig. 5: Putty impression of cleft
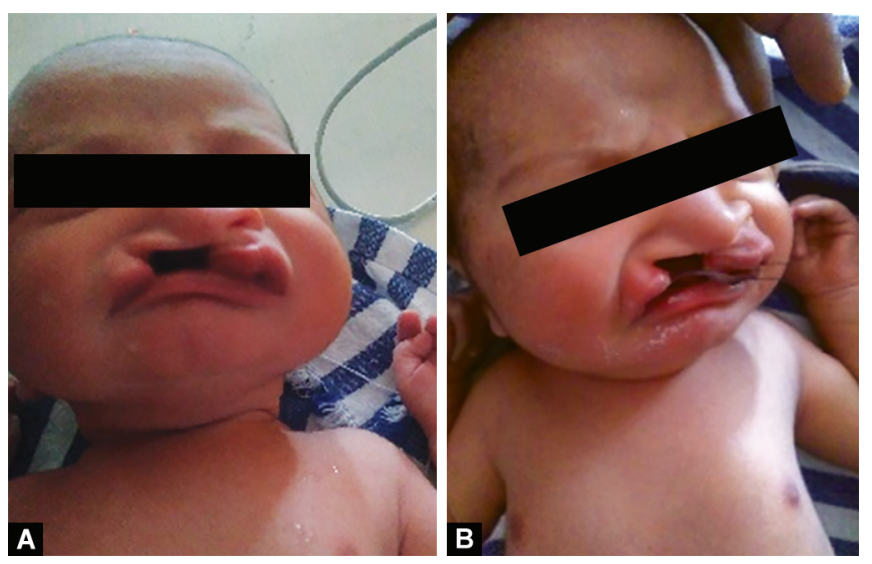

Figs 7A and B: (A) Infant with unilateral complete cleft; (B) Infant with palatal obturator

material, that is, fast-setting addition silicone putty (Zhermack elite $\mathrm{HD}+$ putty soft) and then impression was retaken. Master cast is prepared with type- $V$ dental stone on which obturator is prepared using thermoplastic ethylene vinyl acetate sheet (two layered) using Biostar vacuum-forming machine. Final obturator was cut, 
trimmed, and polished and checked for fit, and before delivery, a hole was placed and 10-inch floss was tied to stabilize during the feeding. Appliance was tried in infant's oral cavity, parents were instructed about the placement and removal of palatal feeding obturator, and instructions were given about cleaning and storage of appliance (Fig. 8).

\section{Case 4}

A 3-month-old female infant with incomplete bilateral isolated palatal cleft was reported. Mother noticed baby was crying excessively during feeding and was not gaining weight, hence consulted a pediatrician regarding the same. The weight of baby at the third month was only $1.5 \mathrm{~kg}$. Feeding obturator was constructed in a similar manner as described above (Fig. 9).

\section{Discussion}

Surgical closure of the cleft palate will be usually planned between 9 months and 18 months of age. Till the cleft palate is surgically closed, feeding the infant is relatively difficult for the mother. Babies with cleft palate have difficulty in breastfeeding and bottle feeding because of their altered/decreased ability to create suction. ${ }^{9}$ Altered sucking is due to lack of proper anatomical structures of

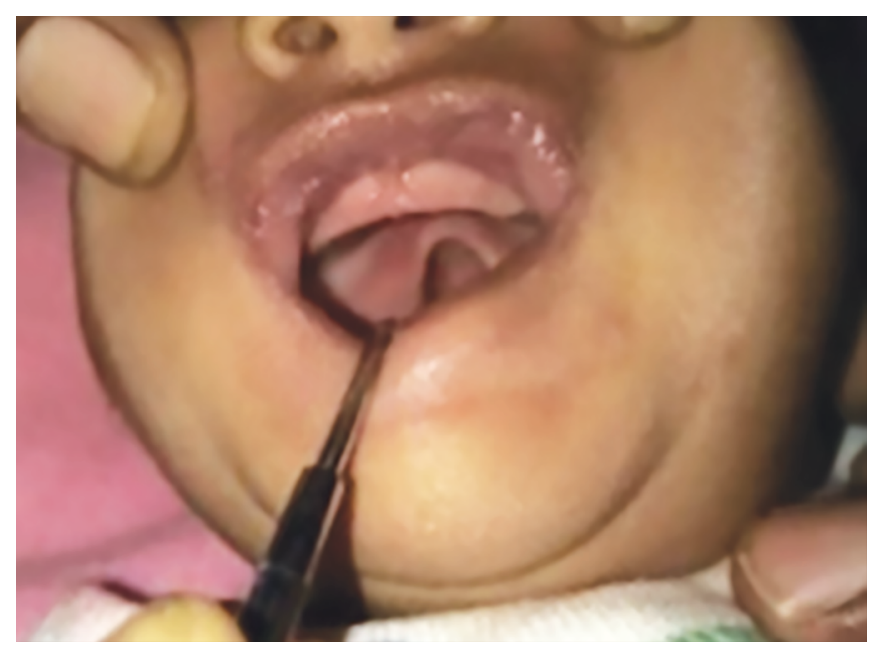

Fig. 8: Infant with uvulopharyngeal cleft
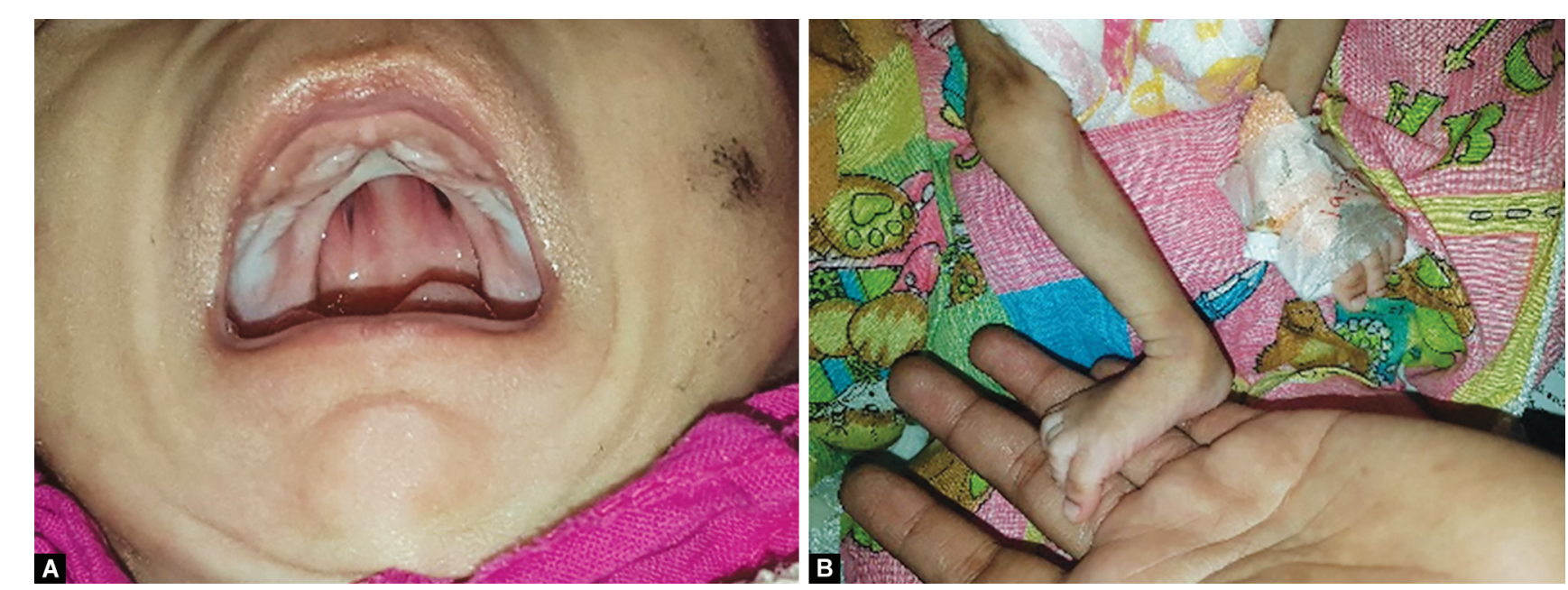

Figs 9A and B: (A) Infant with bilateral incomplete isolated cleft in the palatal region; (B) Signs of malnourishment in infant with bilateral incomplete isolated palatal cleft region hard palate and especially soft palate. ${ }^{8}$ The ability to create suction is hampered more in infants with larger clefts than in infants with smaller clefts. ${ }^{10}$

Various feeding methods and modifications are recommended for feeding infants with CLP such as enlarging the size of hole in the tip of bottle (nipple of the feeding bottle), compress the tip against any existing palatal structures, ${ }^{11}$ squeeze bottles, and feeding tube ${ }^{12}$ usage of Haberman feeder.

Neonatal palatal feeding obturator is indicated when there is difficulty in breast and bottle feeding. Feeding obturator temporarily seals off the connection between oral and nasal cavities, thereby allowing infant to create sufficient pressure, which helps the infant in sucking the milk. Jones et al. reported that palatal obturator allows tongue from protruding into the cleft, thereby allowing normal suckling of milk. ${ }^{13}$ The advantages of feeding obturator include decrease in choking nasal regurgitation and nasal discharge decreased apprehension and time required for feeding. ${ }^{13}$

Some authors report that palatal feeding obturator prevents the interposition of tongue in the cleft area, which allows for spontaneous growth of palatal shelves toward each other but time of placement of palatal obturator is very limited and justification for this statement is lacking.

Impression taking is the most important procedure in fabrication of palatal feeding obturator in infants. The following factors are to be considered while making impression:

\section{Preparation of Infant}

Infant should be fully awake, nonsedated, and some authors recommend not feeding the infant 2 hours prior to impression procedure. $^{14}$

\section{Armamentarium and Setting}

Hospital setting was advocated for impression taking, ${ }^{15}$ highvolume suction should be available all the times to prevent accidental aspiration of separated impression material or regurgitated contents. ${ }^{16,17}$

\section{Position of the Child}

Various positions such as supine position, ${ }^{16}$ face downward position, ${ }^{14,17-19}$ upright position ${ }^{20,21}$ are recommended during impression making. 


\section{Impression Making}

Crying of infant during impression making has the advantages such as it ensures molding of impression material to the anatomic contours of palate, and also, crying ensures an open airway. ${ }^{18}$ Any absence of crying indicates airway obstruction.

\section{Impression Material}

Alginate ${ }^{22-26}$ impression compound, ${ }^{9,21}$ elastomeric impression material polysulfide, ${ }^{27}$ and polyvinyl siloxane ${ }^{18}$ are used for impression making in infants with CLP.

\section{Impression Technique}

Single-step $p^{15,17,18,20,28,29}$ (Table 1) or twostep impression technique ${ }^{9,16,19,23-26,29-32}$ (Table 2) is followed by many authors, but the two-step technique has the advantage of fabrication of custom tray that will reduce the amount of material needed to make final impression and also prevents excess material that has the potential to block the airway. In the two-step impression technique, preliminary impression can be fabricated with self-cure acrylic.

\section{Material}

Various materials are used for fabrication of palatal obturators such as vacuum adapted low-density polyethylene material (ethylene vinyl acetate), $, 18,30$ heat cure acrylic ${ }^{22}$ autopolymerizing self-cure acrylic. $^{21}$ The advantages of ethylene vinyl acetate over acrylicis: its lightweight, moldability, and a good fit to palate and ridges decreased the possibility of soft tissue injury because of soft texture. ${ }^{30}$ The feeding obturator should be adjusted every 2-3 weeks and replaced every $2-3$ months. ${ }^{30}$

Table 1: Table showing case reports with single step impression

\begin{tabular}{lll}
\hline S.no. & Authors & Impression material \\
\hline 1 & Chandna et al. $^{18}$ & Polyvinyl siloxane putty material \\
2 & Shahapur et al. $^{20}$ & $\begin{array}{l}\text { Very high-viscosity polyvinylsiloxane } \\
\text { impression material }\end{array}$ \\
3 & ${\text { Dubey et al. }{ }^{17}}^{\text {Putty-type rubber-base impression }}$ & $\begin{array}{l}\text { Puterial. } \\
\text { mating }\end{array}$ \\
4 & Pesun et al. ${ }^{28}$ & $\begin{array}{l}\text { Fast setting polyvinyl siloxane soft putty } \\
\text { viscosity impression material }\end{array}$ \\
\hline
\end{tabular}

Table 2: Table showing case reports with two step impression

\begin{tabular}{|c|c|c|c|}
\hline S. no. & Authors & $\begin{array}{l}\text { Preliminary impres- } \\
\text { sion }\end{array}$ & Final impression \\
\hline 1 & Savion et al. ${ }^{32}$ & $\begin{array}{l}\text { Impression } \\
\text { compound }\end{array}$ & $\begin{array}{l}\text { Rubber-base } \\
\text { impression } \\
\text { material }\end{array}$ \\
\hline 2 & Agarwal et al. ${ }^{31}$ & & \\
\hline 3 & Ravichandra et al. ${ }^{19}$ & Alginate & $\begin{array}{l}\text { Fast-setting } \\
\text { elastomeric putty } \\
\text { material }\end{array}$ \\
\hline 4 & Bhandari et al. ${ }^{29}$ & $\begin{array}{l}\text { Impression } \\
\text { compound }\end{array}$ & $\begin{array}{l}\text { Light body poly- } \\
\text { vinyl siloxane }\end{array}$ \\
\hline 5 & Bansal et al. ${ }^{16}$ & & \\
\hline 6 & Erkan et al. ${ }^{15}$ & $\begin{array}{l}\text { Viscous vinyl } \\
\text { polysiloxane } \\
\text { impression material }\end{array}$ & $\begin{array}{l}\text { Viscous vinyl } \\
\text { polysiloxane }\end{array}$ \\
\hline 7 & Masih et al. ${ }^{30}$ & Heavy body putty & Heavy body putty \\
\hline 8 & Hansen et al. ${ }^{9}$ & $\begin{array}{l}\text { Impression } \\
\text { compound }\end{array}$ & Alginate \\
\hline
\end{tabular}

\section{Advantages of Feeding Obturator}

A feeding obturator is a device that separates and creates a seal between the oral and nasal cavities. An obturator creates a rigid platform on which a baby can press the tip of feeding bottle and extract milk. It reduces potentially painful ulceration of the nasal septum by the tip of feeding bottle because of the plasticity of the tissue conditioner on the fitting surface of the tissue conditioner. ${ }^{27}$ It helps create sufficient negative pressure that allows for adequate sucking of milk. ${ }^{19}$ It reduces the passage of food into the nasopharynx, thus reducing the incidence of otitis media and nasopharyngeal infections. ${ }^{5}$

\section{Nutritional Gain}

Better results in the nutritional gain was observed in infants with CLP who used palatal obturators for feeding when compared to controls. ${ }^{26,33}$ Turner et al. demonstrated that the combined use of a palatal obturator and lactation education resulted in reduced feeding times, an increased volume consumed, and a higher flow rate. ${ }^{26}$ Prahl-Andersen et al. reported that feeding was better in obturator group than in the nonobturator group, ${ }^{34}$ but there was no significant difference between nutritional gain in obturator group and control group. These results were the same as in the study reported by Masarei et al. ${ }^{35}$

\section{Restoration of Infants Ability to Generate Intraoral Pressure}

Kogo et al. reported that feeding plate creates enough negative pressure that is adequate for sucking of milk. ${ }^{33}$ Such infants can suck and intake about breast milk per attempt, and breastfeed until naturally weaned. However, in another study by Choi et al., the presence or absence of an intraoral orthopedic plate did not make any difference in the ability of infants with clefts to generate negative intraoral pressure. ${ }^{36}$

\section{Tongue Position}

Osuji hypothesized that if an opposing surface in the form of an obturator was provided, cleft infants would produce more normal tongue movements, including compression of the tip of feeding bottle. ${ }^{22}$ However, Masarei et al. suggested that regardless of cleft type or obturator status, all infants show poor tongue coordination. ${ }^{35}$

\section{Problems Associated with the Use of Obturators}

There are hazards associated with while taking impressions for construction of the obturator, such as difficulty in removing the impression due to engagement of undercuts and fragmentation of the impression upon withdrawal from the mouth with subsequent respiratory obstruction and cyanotic episodes. ${ }^{37}$ Repeated construction of new obturators because of baby's growth is often associated with poor oral hygiene, which can lead to fungal growth on the palate if the proper cleaning procedure for the prosthesis is not followed. Intraoral placement of the obturator is challenging and can add to the burden of maintenance. ${ }^{35}$

\section{References}

1. Panamonta V, Pradubwong S, Panamonta M, et al. Global birth prevalence of orofacial clefts: a systematic review. J Med Assoc Thai 2015;98(Suppl 7):S11-S21. 
2. Venkatesh R. Syndromes and anomalies associated with cleft. Indian J Plast Surg 2009;42(Suppl):S51. DOI: 10.4103/0970-0358.57187.

3. Figueiredo JC, Ly S, Magee KS, et al. Parental risk factors for oral clefts among Central Africans, Southeast Asians, and Central Americans. Birth Defects Res A Clin Mol Teratol 2015;103(10):863-879. DOI: 10.1002/bdra.23417.

4. Amstalden-Mendes LG, Magna LA, Gil-da-Silva-Lopes VL. Neonatal care of infants with cleft lip and/or palate: feeding orientation and evolution of weight gain in a nonspecialized Brazilian hospital. Cleft Palate Craniofac J 2007;44(3):329-334. DOI: 10.1597/05-177.

5. Paradise JL, McWilliams BJ. Simplified feeder for infants with cleft palate. Pediatrics 1974;53(4):566-568.

6. Lee J, Nunn J, Wright C. Height and weight achievement in cleft lip and palate. Arch Dis Child 1997;76(1):70-72. DOI: 10.1136/adc.76.1.70a.

7. Miller CK. Feeding issues and interventions in infants and children with clefts and craniofacial syndromes. Semin Speech Lang 2011;32(2):115-126. DOI: 10.1055/s-0031-1277714.

8. Hansen PA, Cook NB, Ahmad O. Fabrication of a feeding obturator for infants. Cleft Palate Craniofac J 2016;53(2):240-244. DOI: 10.1597/14-029.

9. Glass RP, Wolf LS. Feeding management of infants with cleft lip and palate and micrognathia. Infant Young Child 1999;12(1):70-81. DOI: 10.1097/00001163-199907000-00010.

10. Reid J, Reilly S, Kilpatrick N. Sucking performance of babies with cleft conditions. Cleft Palate Craniofac J 2007;44(3):312-320. DOI: 10.1597/05-173.

11. Pashayan HM, McNab M. Simplified method of feeding infants born with cleft palate with or without cleft lip: Hermine M. Pashayan, MD, Margaret McNab, RN. Am J Dis Child 1979;133(2):145-147. DOI: 10.1001/ archpedi.1979.02130020035006.

12. Danner S. Breastfeeding the infant with a cleft defect. NAACOG's Clin Issu Perinat Womens Health Nursing 1991;3(4):634-639.

13. Jones JE, Henderson L, Avery DR. Use of a feeding obturator for infants with severe cleft lip and palate. Spec Care Dentist 1982;2(3):116-120. DOI: 10.1111/j.1754-4505.1982.tb01297.x.

14. Rathee M, Tamrakar AK. Single visit custom made flexible feeding obturator for an infant with tetralogy of fallot. Saudi J Med Med Sci 2015;3(3):226. DOI: 10.4103/1658-631X.162033.

15. Erkan M, Karaçay $S$, Atay $A$, et al. A modified feeding plate for a newborn with cleft palate. Cleft Palate Craniofac J 2013;50(1):109-112. DOI: 10.1597/11-059.

16. Bansal R, Pathak AK, Bhatia B, et al. Rehabilitation of a one-dayold neonate with cleft lip and palate using palatal obturator: a case report. Int J Clin Pediatr Dent 2012;5(2):145. DOI: 10.5005/ jp-journals-10005-1154.

17. Dubey A, Mujoo S, Khandelwal V, et al. Simplified design and precautionary measures in fabrication of a feeding obturator for a newborn with cleft lip and palate. BMJ Case Rep 2013;2013, 10.1136/ bcr-2013-010465.

18. Chandna P, Adlakha V, Singh N. Feeding obturator appliance for an infant with cleft lip and palate. J Indian Soc Pedod Prev Dent 2011;29(1):71. DOI: 10.4103/0970-4388.79950.

19. Ravichandra K, Vijayaprasad K, Vasa A, et al. A new technique of impression making for an obturator in cleft lip and palate patient. J Indian Soc Pedod Prev Dent 2010;28(4):311. DOI: 10.4103/09704388.76165 .

20. Shahapur S, Talikoti A, Basutkar N. Prosthetic Management of nasoalveolar clefts in newborns: a series of case reports. J Indian Prosthodont Soc 2011;11(4):250-253. DOI: 10.1007/s13191-011-0083-8.
21. Muthu M. Management of an infant with cleft lip and palate with phocomelia in dental practice. J Indian Soc Pedod Prev Dent 2000;18(4):141-143.

22. Osuji O. Preparation of feeding obturators for infants with cleft lip and palate. J Clin Pediatr Dent 1994;19(3):211-214.

23. Razek MKA. Prosthetic feeding aids for infants with cleft lip and palate. J Prosthet Dent 1980;44(5):556-561. DOI: 10.1016/00223913(80)90078-5.

24. Jones J, Kerkhof R. Obturator construction for maxillary orthopedics in cleft lip and palate infants. Quintessence Dent Technol 1984;8(9): 583.

25. Goldberg WB, Ferguson FS, Miles RJ. Successful use of a feeding obturator for an infant with a cleft palate. Spec Care Dentist 1988;8(2):86-89. DOI: 10.1111/j.1754-4505.1988.tb00699.x.

26. Turner $L$, Jacobsen $C$, Humenczuk $M$, et al. The effects of lactation education and a prosthetic obturator appliance on feeding efficiency in infants with cleft lip and palate. Cleft Palate Craniofac J 2001;38(5):519-524. DOI: 10.1597/1545-1569_2001_038_0519_ teolea_2.0.co_2.

27. Saunders I, Geary L, Fleming P, et al. A simplified feeding appliance for the infant with a cleft lip and palate. Quintessence Int 1989;20(12):907-910.

28. Pesun IJ, Minski J, Narvey M, et al. Use of an obturator with nCPAP in a premature infant with a cleft lip and palate. J Prosthet Dent 2015;113(5):493-497. DOI: 10.1016/j.prosdent.2015.01.004.

29. Bhandari S, Aras M, Bakshi S. Interim obturator in an infant with Treacher Collins syndrome: review and chairside modification in impression making. Contemp Clin Dent 2011;2(4):342. DOI: 10.4103/0976-237X.91800.

30. Masih S, Chacko RA, Thomas AM, et al. Simplified feeding appliance for an infant with cleft palate. J Indian Soc Pedod Prev Dent 2014;32(4):338. DOI: 10.4103/0970-4388.140970.

31. Agarwal A, Rana V, Shafi S. A feeding appliance for a newborn baby with cleft lip and palate. Natl J Maxillofac Surg 2010;1(1):91. DOI: 10.4103/0975-5950.69149.

32. Savion I, Huband ML. A feeding obturator for a preterm baby with Pierre Robin sequence. J Prosthet Dent 2005;93(2):197-200. DOI: 10.1016/j.prosdent.2004.10.016.

33. Kogo M, Okada G, Ishii S, et al. Breast feeding for cleft lip and palate patients, using the Hotz-type plate. Cleft Palate Craniofac J 1997;34(4):351-353. DOI: 10.1597/1545-1569_1997_034_0350_ bffcla_2.3.co_2.

34. Prahl-Andersen D. Dental treatment of predental and infant patients with clefts and craniofacial anomalies. Cleft Palate Craniofac 2000;37(6):528-532. DOI: 10.1597/1545-1569_2000_037_0528_ dtopai_2.0.co_2.

35. Masarei AG, Sell D, Habel A, et al. The nature of feeding in infants with unrepaired cleft lip and/or palate compared with healthy noncleft infants. Cleft Palate Craniofac J 2007;44(3):321-328. DOI: 10.1597/05185.

36. Choi B, Kleinheinz J, Joos U, et al. Sucking efficiency of early orthopaedic plate and teats in infants with cleft lip and palate. Int J Oral Maxillofac Surg 1991;20(3):167-169. DOI: 10.1016/S09015027(05)80009-8.

37. Sabarinath VP, Hazarey P, Ramakrishna Y, et al. Caring for cleft lip and palate infants: impression procedures and appliances in use. J Indian Prosthodont Soc 2009;9(2):76-80. DOI: 10.4103/0972-4052. 55248. 